\title{
Autoantibodies in Systemic Lupus Erythematosus, on Black African Subject, in Abidjan
}

\author{
Mariam Gbané-Koné, Baly Ouattara, Kouassi Jean Mermoz Djaha, Estelle Megne, \\ Astrid Nawé Ngandeu, Abidou Kawalé Coulibaly, Edmond Eti, Marcel N’zué Kouakou \\ Department of Rheumatology, University Hospital Center of Cocody, Abidjan, Côte d'Ivoire \\ Email: mariamgbane05@yahoo.fr
}

Received 6 March 2015; accepted 3 April 2015; published 8 April 2015

Copyright (C) 2015 by authors and Scientific Research Publishing Inc.

This work is licensed under the Creative Commons Attribution International License (CC BY). http://creativecommons.org/licenses/by/4.0/

(c) (i) Open Access

\begin{abstract}
Aim: To determine the clinical and immunological characteristics of patients with systemic erythematosus lupus in Abidjan. Patients and Method: We studied 117 patients' files with systemic lupus erythematosus aged 12 to 73 years old, who fulfilled the American College of Rheumatology (ACR)'s criteria. Antinuclear autoantibodies (ANA) were searched by indirect immunofluorescence. Anti-DNA native autoantibodies, extractable nuclear anti-antigens autoantibodies (anti-Sm, anti-SSA, anti-SSB and anti-RNP) and anti-phospholipids autoantibodies have been searched by ELISA technic. Results: The most frequent clinical manifestations were: articular damages $(86.32 \%)$, cutaneous and mucosal lesions (71.79\%) and fever (76.67\%). Kidney damages have been noticed in $\mathbf{4 0 . 1 7 \%}$. Neurologic manifestations have been observed in $\mathbf{3 6 . 7 5 \%}$. Pericarditis and pleurisies have been noticed in $22.22 \%$ and $11.97 \%$ of cases, and anaemia in $86.32 \%$ of cases. ANA have been detected in $94.12 \%$ of cases, anti-DNA native's autoantibodies in $73.53 \%$ and anti-Sm autoantibodies in $\mathbf{7 5 \%}$ of cases. Anti-SS-A and anti-SS-B autoantibodies were respectively in $75 \%$ and $56.25 \%$ of cases. Anti-RNP autoantibodies were in all the patients, and anti-phospholipids autoantibodies were in $\mathbf{3 7 . 5 0 \%}$ of cases. Conclusion: Systemic lupus erythematosus of Ivorian black subject is characterised by high prevalence of autoantibodies, mostly Anti-RNP.
\end{abstract}

\section{Keywords}

Sub-Saharan Africa, Systemic Lupus Erythematosus, Extractable Nuclear Anti-Antigens, Autoantibodies, Anti-Phospholipids Autoantibodies, ELISA

\section{Introduction}

Systemic lupus erythematosus (SLE) is an autoimmune disease, non-specific to any organ, characterised by the

How to cite this paper: Gbané-Koné, M., Ouattara, B., Djaha, K.J.M., Megne, E., Ngandeu, A.N., Coulibaly, A.K., Eti, E. and Kouakou, M.N. (2015) Autoantibodies in Systemic Lupus Erythematosus, on Black African Subject, in Abidjan. Open Journal of Rheumatology and Autoimmune Diseases, 5, 28-35. http://dx.doi.org/10.4236/ojra.2015.52006 
production of a high variety of autoantibodies, some of which have a direct pathogenic role [1] [2]. Hormonal factors, environmental and genetics factors intervened in the physiopathology [3]. Clinically, SLE is characterised by its polymorphism. We have more and more data on SLE in sub-Saharan Africa [4]-[7] on black subject more specifically particular [3]. Many workers from English or French speaking black Africa have reported the frequency of different clinical and biological manifestations of lupus [3]-[7].

In Ivory Coast, the study realised by Daboiko [4] in 2004 had mostly described epidemio-clinical aspects of SLE on black subject; our work is coming in addition to complete. It aims to describe autoantibodies profile in SLE on black African subject in Abidjan.

\section{Patients and Method}

It was a descriptive and retrospective study, carried out on a retrospective setup over 27 years from 1987 to December 2014 the rheumatology department's record. The following criteria were considered for the patients: should have consulted or have been hospitalized in the rheumatology department during the study period; the SLE diagnostic have been retained in front of at list 4 criteria of ACR. The patient's age at the diagnostic period matches to the age where the patient respond to ACR criteria's. For each patient, a form was design, which included clinical manifestations of the disease, blood numeration formula, sedimentation rate, C-reactive protein, and the 24 hours proteinuria.

Immunological investigations had anti-nuclear autoantibodies factors in all the cases; anti-DNA autoantibodies research and anti ENA (anti-Sm, anti-URN-P, anti SSA, anti SSB, Anti Scl 70); and anticardiolipins, rheumatoid factors, and anti-CCP. Immunological samples (ANA, Anti ENA, Anti CCP, Antiphospholipid) were all routed in France (Cerba laboratory) for analysis.

Antinuclear autoantibodies (AAN) were researched using indirect immunofluorescence technic. Anti-DNA native autoantibodies (anti-Sm, anti-SS-A, anti-SS-B and anti-RNP); and antiphospholipids autoantibodies (anticardiolipine: acL) have been researched by ELISA technic.

This investigation was approved by the local Ethics Committee.

\section{Results}

\subsection{Prevalence}

On a sample of 18076 patients hospitalised during the study period, 117 SLE files have been found, thus a $0.64 \%$ prevalence in hospitalisation.

\subsection{Age}

The average age during the diagnosis was 35.76 years old, with a standard deviation of 11.956 and extremes of ages of 12 and 73 years old.

The most affected age group was that of 21 - 40 years (Figure 1).

\subsection{Sex}

There were 115 females (98.3\%) and 02 males (1.7\%), with a sex ratio (F/M) of 57.5.

\subsection{Clinical Manifestations}

The main clinical manifestations are illustrated on Table 1.

Articular damages constituted the most frequent clinical manifestations, because observed on $86.32 \%$ of patients. Most of the time it was arthralgia most of the time (53\%). Myalgia represented $14 \%$ of cases.

An articular deformation, Jacoud's hand, was observed on 6 female patients. Fever, was the most frequent general symptom $(76.07 \%)$.

Principal cutaneous manifestations were butterfly rash (43.59\%) and photosensitivity (41.90\%).

\subsection{Biological Characteristics}

Table 2 outlines the principal biological and immunological anomalies research on this study.

Anaemia was the principal haematological anomaly. Inflammatory syndrome was quasi constant $(96.58 \%$ of cases). 


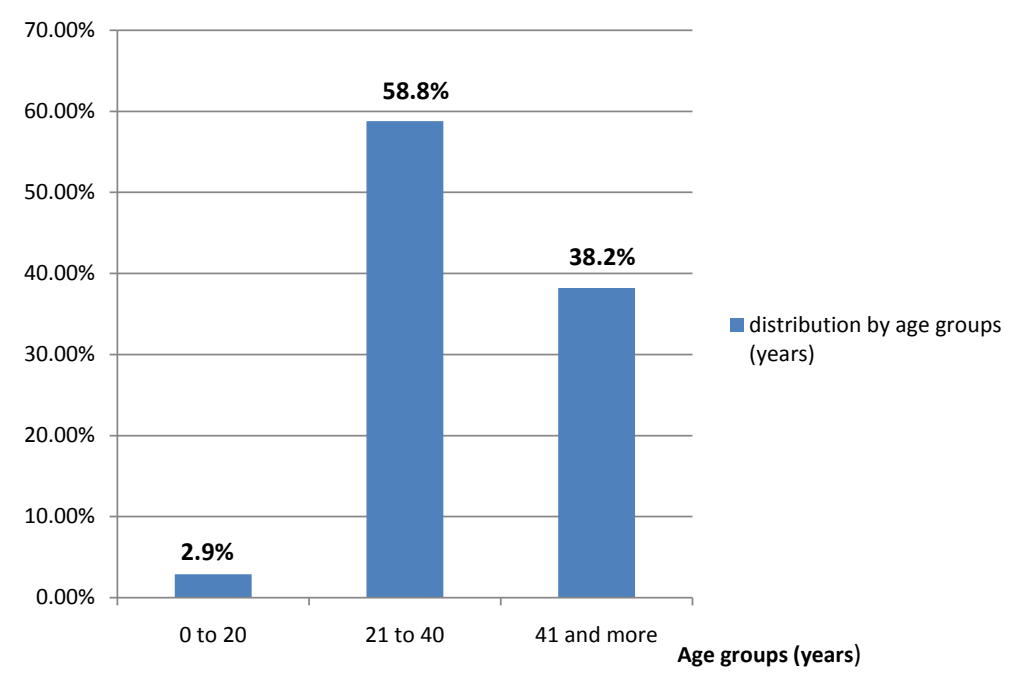

Figure 1. Distribution of SLE patients by age groups.

Table 1. Clinical manifestations of 117 SLE monitored in Abidjan.

\begin{tabular}{|c|c|c|}
\hline Clinical manifestations & Number of cases & Prevalence (\%) \\
\hline Articular signs & 101 & 86.32 \\
\hline Arthralgia & 62 & 53 \\
\hline Arthritis & 49 & 41.90 \\
\hline General signs & 89 & 76.07 \\
\hline Long-term fever & 89 & 76.07 \\
\hline Changed general body state & 75 & 64.10 \\
\hline Mucocutaneous signs & 84 & 71.79 \\
\hline Facial erythema & 53 & 43.59 \\
\hline Alopecia & 37 & 31.62 \\
\hline Oral ulcerations & 19 & 16.23 \\
\hline Photosensitivity & 49 & 41.90 \\
\hline Discoid lupus & 6 & 5.13 \\
\hline Neuropsychiatric signs & 43 & 36.75 \\
\hline $\mathrm{CVA}^{*}$ & 8 & 6.83 \\
\hline Convulsions & 20 & 17.09 \\
\hline Confusional syndrome & 10 & 8.55 \\
\hline Psychomotor agitation & 6 & 5.13 \\
\hline Pulmonary signs & 41 & 35.04 \\
\hline Pleurisy & 14 & 11.97 \\
\hline Pneumopathy/diffuse interstitial fibrosis & 27 & 23.07 \\
\hline Kidneys signs & 47 & 40.17 \\
\hline Proteinuria & 41 & 35.04 \\
\hline $\mathrm{CKD}^{*}$ & 11 & 9.40 \\
\hline Cardiac signs & 35 & 29.91 \\
\hline Pericarditis & 26 & 22.22 \\
\hline Myocarditis & 9 & 7.69 \\
\hline Splenic and ganglionic signs & 14 & 11.97 \\
\hline Superficial adenopathy & 14 & 11.97 \\
\hline Splenomegaly & 5 & 4.27 \\
\hline Raynaud's syndrome & 10 & 8.54 \\
\hline
\end{tabular}

CVA*: Cerebral Vascular Accident; CKD*: Chronic Kidney Disease. 
Table 2. Biological and immunological anomalies of 117 SLE monitored in Abidjan.

\begin{tabular}{|c|c|c|c|}
\hline Biological and immunological manifestations & Effectives (n) & Total patients (N) & Prevalence (\%) \\
\hline Haematological manifestations & 101 & 117 & 86.32 \\
\hline Anaemia & 101 & & 86.32 \\
\hline Leukopenia & 18 & & 15.38 \\
\hline Thrombocytopenia & 16 & & 13.67 \\
\hline Inflammatory syndrome & 113 & 117 & 96.58 \\
\hline Sedimentary rate & 113 & & 96.58 \\
\hline $\mathrm{C}$ reactive protein & 46 & & 39.31 \\
\hline ANA & 32 & 34 & 94.12 \\
\hline Anti DNA native & 25 & 34 & 73.53 \\
\hline Anti-ENA & 16 & 21 & 76.20 \\
\hline Anti-Sm & 12 & 16 & 75 \\
\hline $\mathrm{U}_{1} \mathrm{RNP}$ & 16 & & 100 \\
\hline Anti SSA/Ro & 12 & & 75 \\
\hline Anti SSB/La & 9 & & 56.25 \\
\hline Anti- $\mathrm{Jo}_{1}$ & 2 & & 12.50 \\
\hline Anti-Scl70 & 2 & & 12.50 \\
\hline Ac antiphospholipids & 6 & 16 & 37.50 \\
\hline
\end{tabular}

ANA were positive in $94.12 \%$ of cases with a speckled most frequently aspect (58.8\%) or homogenous (26.5\%). Anti-DNA native were tested positive on $73.53 \%$ of cases and anti ENA on $76.20 \%$.

Anti-Sm was positive on $75 \%$ of cases. Antiphospholipids research was positive on $37.50 \%$ of cases.

On the 26 patients who have been realised the rheumatoid factors, 14 were ended up being positives.

Eight patients have realised the anti-CCP dosage, and all of them where negatives.

\section{Discussion}

\section{Limitations of the Study}

The review of literature series only acted as a reference. Clinical signs have not been reported in the same conditions in all the series, the prevalence of a clinical manifestation changes according to whether it was considered at the moment of the diagnosis only; or during the patients monitoring, and the immunological tests have not been realised in the same conditions and with the same technics. In our case, the cost and accessibility of immunological tests (ANA, Anti ENA, Anti CCP, Antiphospholipid) constituted a barrier to diagnosis, immunological samples were all routed in France (Cerba laboratory) for analysis. All these factors may influence the prevalence of various signs and their variability from one series to another.

As Daboiko reported [4] in his sample of 49 lupic in Abidjan, the average age and the population reported in our study, did not have particularities. The clinical predominance is classic [1]-[3], in fact the SLE is a young woman pathology [1]-[4]. The average age of onset was 35.76 years old. This predominance is less pronounced at the bounding ages, this confirms the hypothesis of endocrine factors implication in the disease ethiopathogeny [1].

Our study confirms the clinical polymorphism of SLE in Abidjan and its high similitude with other regions of Africa (Table 3).

Clinical manifestations generally associated cutaneo-articular damages, kidneys, cardiovascular, pleuropulmonary and neurologic damages, with some differences according to the country studied (Table 3). 
Table 3. Compared frequency of SLE ACR criteria many series of literature.

\begin{tabular}{|c|c|c|c|c|c|c|}
\hline & $\begin{array}{c}\text { Tunisia } \\
(\mathrm{n}=295)\end{array}$ & $\begin{array}{l}\text { Morocco } \\
(\mathrm{n}=\mathbf{4 4 0})\end{array}$ & $\begin{array}{c}\text { Gabon } \\
(\mathbf{n}=37)\end{array}$ & $\begin{array}{c}\text { Senegal } \\
(\mathrm{n}=142)\end{array}$ & $\begin{array}{c}\text { Ivory-coast } \\
(\mathbf{n}=117)\end{array}$ & $\begin{array}{c}\text { Cameroon } \\
(\mathrm{n}=39)\end{array}$ \\
\hline Cutaneous damages & 82 & 85.2 & 62.1 & 90.8 & 71.79 & - \\
\hline Butterfly rash & 62 & _ & _ & 43 & 43.59 & 15.4 \\
\hline Discoid lupus & 9 & _- & - & 27.5 & 14.53 & 5.1 \\
\hline Photosensitivity & 46 & _ & _ & 57.7 & 41.9 & 7.7 \\
\hline Oral ulcerations & 15 & - & - & 4.2 & 16.23 & 10.3 \\
\hline Articular damages & 90 & 95 & 59.4 & 68.3 & 86.32 & 58.9 \\
\hline Seritis & 31 & 24.1 & - & 9.9 & _ & 10.3 \\
\hline Kidney damages & 56 & 45.9 & 16.2 & 49.3 & 40.17 & 17.9 \\
\hline Neurologic damages & 14.5 & 25.3 & 24.3 & 17.6 & 36.75 & 10.3 \\
\hline Anaemia & 6.7 & - & - & 49.2 & 86.32 & 72 \\
\hline Leukopenia & 45 & _ & - & 19.7 & 15.38 & 56 \\
\hline Lymphocytopenia & 47 & - & - & 14.8 & - & 44 \\
\hline Thrombocytopenia & 16 & _ & - & 13.4 & 13.67 & 16 \\
\hline AC Anti-DNA & 74 & 73.4 & 63.8 & 45.7 & 73.53 & 73.5 \\
\hline Anti Sm & 57 & 16.6 & 33.33 & 65.2 & 75 & - \\
\hline Ig aCL ${ }^{*}$ & 45 & 27.1 & - & 50 & 37.5 & 50 \\
\hline Anti-nuclear & 92 & 95 & 100 & 97.8 & 94.12 & 86.1 \\
\hline
\end{tabular}

Ig aCL ${ }^{*}$ : Ig anticardiolipin.

In our study, articular manifestations were at the first considered, followed by general manifestations and cutaneous damages common for Cameroonian series [7], Moroccan [8] and Tunisian [9], however for Senegalese series [6] and Gabonese [5], cutaneous damages were most frequently followed by articular damages.

Articular damages inaugurate the disease in $50 \%$ of cases [1] [2]. Arthralgia are frequent (53\% in our series), they are often coming with myalgia. Arthritis realise habitually a bilateral and symmetric polyarthritis.

Cutaneous damage's prevalence varies between 32\% and 72\% [10] [11]. Butterfly rash, SLE characteristic has been noticed on $43.59 \%$ of cases in our series.

Kidney damages are the second causes mortality of SLE. Its frequency varies depending on the series between $13 \%$ and $73 \%$ [1] [2] [9] [12] [13]. In our study it was $40.17 \%$. It was consistenly less elevated in Gabonese series $(16.2 \%)$ and Cameroonian (17.9\%). Glomerular damage is the characteristic lesion, it manifest by a frank proteinuria [2].

Neurological damages constitute the third cause of SLE mortality after infectious complications and kidney damage [2].

Neuropsychiatric manifestations have a variable frequency of $30 \%$ to $60 \%$ according to series [14] [15]. It was of $36.75 \%$ in our study.

Cardiac manifestations interest the tree heart tunics with a predilection for pericardia [2]. Pericarditis has been reported on $22.22 \%$ of the cases in our study.

Pleurisy, reported on $11.97 \%$ of cases in our series is the most common pulmonary manifestation during SLE [1] [2]. Its frequency varies in literature from $10 \%$ up to 52\% [2] [9] [13] [16].

In our countries with high tuberculosis endemicity, it is more often considered like tuberculosis and cured like it. In ours ample, interstitial pneumopathy was the most frequent of pulmonary damages.

The biological anomalies found in our sample are similar to literature data [5]-[7].

An anaemia is habitual, and most often inflammatory [1]-[3] [5]-[7] [9]. It reveals sometimes the SLE. Its frequency varies in literature from $8 \%$ up to $67 \%$ [2] [10] [17]. It was the haematological perturbation most fre- 
quently seen in our study (86.32\%). This high frequency of anaemia also constitutes one of the black subject particularities [3]. Indeed, during compared studies of SLE realised by Petri [17] between black and white Americans subjects, it has been proved a high anaemia frequency on the black American subject.

On the other hand, haemolytic anaemia, SLE characteristic is rare [9] [12] [16].

Leukopenia frequency varies according to series from $18 \%$ up to 83\% [1] [2] [16]-[18]. It was slightly elevated (15.38\%) in our study. Our frequency was sensibly equal to that of Senegal one [6], however it was most highest (56\%) in Douala's study in Cameroon [7]. The leukopenia is frequent on the black subject [3]-[20].

Thrombocytopenia's frequency varies from $10 \%$ up to $26 \%$ in the literature [9] [12] [20], it is $13.67 \%$ in our sample. Idem for Senegal [6] and Cameroon [7], it can be associated to haemolytic anaemia (Evans' syndrome).

In unanimous way, ANA are quasi-constant in SLE, in fact, antinuclear autoantibodies are positives in most in 90\% of the time in African studies: 92\% in Tunisia [9], 95\% in Morocco [8], 100\% at Gabon [5]; 97.8\% in Senegal [6], 94.2\% in our study.

Cameroon alone had a rate below 90\% (86.1\%). These high rates are the same found in American and European studies (99\% on North-American [21]; 96\% in European study [12] and Brazilian [22].

Detection of anti DNA native autoantibodies in our study was 73.53\%. This frequency was similar to the one observed in Africa (Tunisia [9], Morocco [8], Cameroon [7]) and North America [21] and in Europe [12] but it was clearly far high than Gabonese study [5] or Senegalese [6] where Anti-DNA natives, haven't been positives on respectively $63.8 \%$ and $45.7 \%$ of cases. This can be explained by the variable sensitivity of the different research technics indeed the anti-DNA natives frequency vary from $35 \%$ up to $98 \%$ depending on series and technics used [1] [2] [10] [13] [23]-[25].

Elevated rates of anti-DNA native's autoantibodies are specific from SLE. The anti-DNA native's autoantibodies rate is correlated to a serious kidney damage existence, and to the Systemic Lupus Erythematous evolution [26].

Extractable nuclear anti-antigens autoantibodies frequency during SLE, also varies depending on the sensibility of the methods used, depending on series and sometimes depending on ethnic origin [2].

Anti-Sm autoantibodies are exclusively present on lupic patients.

Their incidence varies from $12 \%$ up to 52\% [2] [13] [23] [24] [27] [28]. The anti-Sm's sensibility is particularly elevated on black subjects, in order of 50\% [3]-[9] [19] [20], compared to the Caucasian population, where anti-Sm are found on only $10 \%$ to $20 \%$ of SLE cases [12]. This has been confirmed in the Senegalese series [7] and in ours, where the anti-SM frequency was elevated respectively in $65.2 \%$ and $75 \%$ of cases respectively. However, it was clearly lower in the Gabonese series (33.33\%) [5]. This low frequency could be explained by the realisation technics. ELISA technic is actually the reference method [2].

Anti-RNP was present in all our patients (100\%) versus 66\% in the Tunisian series [9] and 78.3\% at Senegal [6]. Anti-ribonucléoproteins autoantibodies (anti-RNP) can been observed on $20 \%$ to $30 \%$ of lupus, but are not specific to Systemic lupus erythematous [29]. However, it has been showed a more high frequency of anti- RNP on the black African [3]. Indeed, during compared studies of clinical and biological manifestations between black Africans and Caucasians living in Europe [30] or in South Africa [31], it has been found on black Africans higher frequency of anti-RNP, in addition to myalgia, seritis and kidney insufficiency.

Anti-SS-A autoantibodies have a high predictive value for SLE diagnosis among the patients tested positive on AAN, but negatives on anti-DNA native autoantibodies or Anti Sm [1] [2]. Indeed, in Simmons O'Brien et al.'s study [32], he found that $47 \%$ of patients with kidney damage had anti-SS-A autoantibodies but not antiDNA native autoantibodies. Patients with anti-SS-A autoantibodies have to be regularly followed to detect the onset of systemic manifestations [32]. Anti-SSA frequency varies during SLE from 20\% to $60 \%$ according to series [2] [9] [12] [13], in our study, the frequency was high (75\%).

Anti-SSB autoantibodies, are particularly frequent in primitive Sjogren' syndrome (60\% to $80 \%$ ) while their frequency in SLE is variable according to series, to 5\% up to 35\% [1] [12] [13] [33]. Their frequency was slightly higher (56.25\%) in our study. The elevated frequency of anti SSA and SSB could also be a SLE particularity in black subjects [3].

Antiphospholipids frequencies during SLE varies according to series from $17 \%$ up to 87\% [1] [2] [9] [12] [13]. It was $37.50 \%$ in our study. It was higher in Tunisian [9], Senegalese [6] and Cameroonian [7] studies respectively $45 \%$ and $50 \%$ of cases.

This study shows an increase in SLE in Ivory Coast and a better knowledge of the clinical and immunological profile by the amelioration of the technical expertise and the growing augmentation of rheumatologists. 


\section{Conclusion}

Our study confirms the SLE clinical polymorphism on one hand, and on the other hand reveals that the lupic serology of black subjects is rich with the existence of multiple types of antinuclear autoantibodies simultaneously (Anti-DNA, Anti-Sm, Anti-RNP, Anti-SSA, Anti-SSB).

\section{Conflicts of Interests}

Authors have no conflicts of interest to declare.

\section{References}

[1] Haddouk, S., Ben Ayed, M., Baklouti, S., Hachicha, J., Bahloul, Z. and Masmoudi, H. (2005) Autoanticorps dans le lupus érythémateux systémique : Profil et corrélations cliniques . Pathologie Biologie, 53, 311-317. http://dx.doi.org/10.1016/j.patbio.2004.10.004

[2] Ghedira, I., Sakly, W. and Jeddi, M. (2002) Caractéristiques cliniques et sérologiques du lupus érythémateux systémique: A propos de 128 cas. Pathologie Biologie, 50, 18-24. http://dx.doi.org/10.1016/S0369-8114(01)00262-0

[3] Meyer, O. (2002) Lupus systémique chez les non-Caucasiens. Revue du Rhumatisme, 69, 801-808. http://dx.doi.org/10.1016/S1169-8330(02)00385-X

[4] Daboiko, J.C., Gueret, M., Eti, E., Ouali, B., Ouattara, B., Gbané, M. and Kouakou, N.M. (2004) Profil clinique et évolutif du lupus érythémateux systémique: A propos de 49 cas colligés au CHU de Cocody. Médecine d'Afrique noire, 51, 143-146.

[5] Iba Ba, J., Nzenze, J.R., Biteghe, B., Missounga, L., Bignoumba Ibouili, R., Moussavou Kombila, J.B. and Boguikouma, J.B. (2011) Profil clinique, biologique et évolutif du lupus systémique en milieu hospitalier à Libreville. Médecine d'Afrique noire, 58, 551-559.

[6] Fall, S., Pouye, A., Ndiaye, F.S., Ndongo, S., Leye,Y., Diouma,A., Dieng, M.T., Ka, E.F., Ka, M.M. and Moreira-Diop, T. (2011) Présentation initiale du lupus érythémateux systémique au Sénégal. Médecine d'Afrique noire, 58, 156-160.

[7] Doualla Bija, M., Luma Namme, H., Ashuntantang, G., Epée, H., Kemta, F., Kwedi, F., Ngatat, C. and Ngandeu Singwe, M. (2014) Clinical Presentation, Treatment and Outcome of Patients with Systemic Lupus Erythematosus Seen at a Rheumatology Clinic in Douala, Cameroon. Health Sciences and Disease, 15, 1-5.

[8] Bouatba, L., Bachir, H., Ammouri, W., Maamar, M., Harmouche, H., Adnaoui, M. and Tazi Mezalek, Z. (2014) Lupus érythémateux systémique au Maroc: Etude analytique monocentrique de 440 patients. Revue de médecine interne, 35, A96-A200. http://dx.doi.org/10.1016/j.revmed.2014.10.243

[9] Louzir, B., Othmani, S. and Ben Abdelhafidh, N. (2003) Le lupus érythémateux systémique en Tunisie. Étude multicentrique nationale. À propos de 295 observations. La revue de médecine interne, 24, 768-774. http://dx.doi.org/10.1016/S0248-8663(03)00250-9

[10] Vilá, L.M., Mayor, A.M., Valentín, A.H., Garcia-Soberal, M. and Vilá, S. (1999) Clinical and Immunological Manifestations in 134 Puerto Rican Patients with Systemic Lupus Erythematosus. Lupus, 8, 279-286. http://dx.doi.org/10.1191/096120399678847803

[11] Al-Attia, H.M. and Al-Ahmed, Y.H. (1998) Mucocutaneous Disease in Arabs with SLE: Clinical Expression and Relevance to Autoantibodies. Lupus, 7, 535-539. http://dx.doi.org/10.1191/096120398678920569

[12] Cervera, R., Khamashta, M.A., Font, J., Sebastiani, G.D., Gil, A., Lavilla, P., et al. (1993) Systemic Lupus Erythematosus: Clinical and Immunological Patterns of Disease Expression in a Cohort of 1000 Patients. The European Working Party on Systemic Lupus Erythematosus. Medicine, 72, 113-124. http://dx.doi.org/10.1097/00005792-199303000-00005

[13] Al Mekaimi, A., Malaviya, A.N., Serebour, F., Umamaheswaran, I., Kumar, R., Al-Saeid, K. and Sharma, P. (1997) Serological Characteristics of Systemic Lupus Erythematosus from a Hospital-Based Rheumatology Clinic in Kuwait. Lupus, 6, 668-674. http://dx.doi.org/10.1177/096120339700600808

[14] West, S.G. (1996) Lupus and the Central Nervous System. Current Opinion in Rheumatology, 8, 408-414. http://dx.doi.org/10.1097/00002281-199609000-00004

[15] ACR Ad Hoc Committee on Neuropsychiatric Lupus Nomenclature (1999) The American College of Rheumatology Nomenclature and Case Definitions for Neuropsychiatric Lupus Syndromes. Arthritis \& Rheumatology, 42, 599-608.

[16] Uthman, I., Nasr, F., Kassak, K. and Masri, A.B. (1999) Systemic Lupus Erythematosus in Lebanon. Lupus, 8, 713-715. http://dx.doi.org/10.1191/096120399678841016

[17] Petri, M. (1997) The Effect of Race on the Presentation and Course of SLE in the United States. Arthritis \& Rheuma- 
tology, 40, S162.

[18] Al-Jarallah, K., Al-Awadi, A., Siddiqui, H., Al-Salim, I., Shehab, D., Umamaheswaran, I., et al. (1998) Systemic Lupus Erythematosus in Kuwait Hospital Based Study. Lupus, 7, 434-438. http://dx.doi.org/10.1191/096120398678920389

[19] Vilarinho, S.T. and Lavras-Costallat, L.T. (1998) Evaluation of the Hypothalamic-Pituitary-Gonadal Axis in Males with Systemic Lupus Erythematosus. Journal of Rheumatology, 25, 1097-103.

[20] Meyer, O., Lupus érythémateux aigu disséminé (1997) Diagnostic, évolution, principes du traitement. Revue du Praticien, 47, 821-831.

[21] Tan, E.M., Cohen, A.S., Fries, J.F., Masi, A.T., Mc Shane, D.J., Rothfield, N.F., et al. (1982) The 1982 Revised Criteria for the Classification of Systemic Lupus Erythematosus. Arthritis \& Rheumatology, 25, 1271-1277. http://dx.doi.org/10.1002/art.1780251101

[22] Chahade, W.H., Sato, E.L., Moura, J.E., Costallat, L.T.L. and Andrate, L.E.C. (1995) Systemic Lupus Erythematosus in Sao Paulo/Brazil: A Clinical and Laboratory Overview. Lupus, 4, 100-103. http://dx.doi.org/10.1177/096120339500400204

[23] Molina, J.F., Molina, J., Garcia, C., Gharavi, A.E., Wilson, W.A. and Espinoza, L.R. (1997) Ethnic Differences in the Clinical Expression of Systemic Lupus Erythematosus: A Comparative Study between African-American and Latin American. Lupus, 6, 63-67. http://dx.doi.org/10.1177/096120339700600109

[24] Lopez-Longo, F.J., Monteagudo, I., Gonzalez, C.M., Grau, R. and Carreno, L. (1998) Anti-BB'-Sm Antibodies, Anticardiolipin Antibodies and Thrombosis in Systemic Lupus Erythematosus. The Journal of Rheumatology, 25, 17431749.

[25] Lenert, P., Felle, D., Lenert, G., Mitic, I., Curic, S. and Vodopivec, S. (1993) Immunologic Characterization of Autoreactivity to Nuclear Antigens in Patients with Systemic Lupus Erythematosus. Medicinski Pregled, 46, 167-172.

[26] Fournel, S. and Levastre, P. (2000) Les autoanticorps dans le lupus. Médecine Thérapeutique, 6, 537-546.

[27] Pan, L.T., Tin, S.K., Boey, M.L. and Fong, K.Y. (1998) The Sensitivity and Specificity of Auto-Antibodies to the Sm Antigen in the Diagnosis of Systemic Lupus Erythematosus. Annals Academy of Medicine Singapore, 27, 21-23.

[28] Meyer, O. (1999) Biologie du lupus érythémateux systémique. Revue du Rhumatisme, 66, 75s-80s.

[29] Goetz, M. (2005) Marqueurs biologiques anciens et modernes du lupus erythémateux systémique. Revue du Rhumatisme, 72, 134-141. http://dx.doi.org/10.1016/j.rhum.2004.12.007

[30] Amoura, Z., Du, L.T.H., Cacoub, P., Frances, C. and Piette, J.C. (1999) Systemic Lupus Erythematosus in Patients Native to West and Central Africa: Comment on the Article by Bae et al. Arthritis \& Rheumatism, 42, 1560-1561. http://dx.doi.org/10.1002/1529-0131(199907)42:7<1560::AID-ANR42>3.0.CO;2-L

[31] Morrisson, R.C.A., Gear, A.J., Kark, A., Meyers, A. and Goldberg, B. (1990) Differences in Systemic Lupus Erythematosus among 4 Racial Groups in South Africa. Arthritis \& Rheumatism, 33, S104.

[32] Simmons-O’Brien, E., Chen, S., Watson, R., Antoni, C., Petri, M., Hochberg, M., et al. (1995) One Hundred Anti-Ro (SS-A) Antibody Positive Patients: A 10 Year Follow-Up. Medicine, 74, 109-130. http://dx.doi.org/10.1097/00005792-199505000-00001

[33] Buján, S., Ordi-Ros, J., Paredes, J., Mauri, M., Matas, L., Cortés, J. and Vilardell, M. (2003) Contribution of the Initial Features of Systemic Lupus Erythematosus to the Clinical Evolution and Survival of a Cohort of Mediterranean Patients. Annals of the Rheumatic Diseases, 62, 859-865. 